\title{
Water, Sanitation, and Health in Sub-Saharan Africa: A Cross-national Analysis of Maternal and Neo-natal Mortality
}

Jamie M. Sommer

Department of Sociology,

State University of New York at Stony Brook, Stony Brook, United States

John M. Shandra'

Department of Sociology,

State University of New York at Stony Brook, Stony Brook, United States

Michael Restivo

Department of Sociology,

State University of New York at Geneseo, Geneseo, United States

Carolyn Coburn

Department of Sociology,

State University of New York at Stony Brook, Stony Brook, United States

\section{Abstract}

We examine the impact of access to an improved water source and sanitation facility on maternal and neo-natal mortality. We analyze data from a sample of 32 Sub-Saharan African nations from 1990 to 2005 using a two-way fixed effects regression model. We find that access to both improved water and sanitation facilities are associated with decreased maternal and neo-natal mortality. We also consider other structural barriers or facilitators of good reproductive health and find that International Monetary Fund structural adjustment, gross domestic product per capita, female educational attainment, and conflict intensity are related to maternal and neo-natal mortality. We conclude by talking about the theoretical implications, methodological implications, policy suggestions, and directions for future research.

Keywords: water, sanitation, Sub-Sahara, mortality

\footnotetext{
1 Thanks to Andrew Jorgenson and Tom Dietz for editing the special issue. Thanks to the anonymous reviewer for the helpful comments. The authors are listed reverse alphabetically. Please direct correspondence to John M. Shandra at John.Shandra@stonybrook.edu.
} 


\section{Introduction}

The World Health Organization estimates that 289,000 women die from pregnancy complications and 3,000,000 infants die during the first 28 days after birth annually (World Bank, 2015). Nevertheless, maternal and neo-natal infant mortality are not distributed equally. Sub-Saharan Africa has the highest levels of maternal and neo-natal mortality in the world (World Bank, 2015). In 2005, approximately 614 women died during pregnancy or one month afterwards per 100,000 live births and 38 infants died before reaching 28 days per 1,000 live births (World Bank, 2015).

Recently, cross-national research has been published that focuses on structural political-economic explanations for why maternal mortality is so high in the region. For instance, Pandolfelli, Shandra, and Tyagi (2014) find that International Monetary Fund structural adjustment is associated with increased maternal mortality in Sub-Saharan Africa. The authors find that this may well be the case because the International Monetary Fund requires recipient nations to cut government spending for health, implement user fees for services, and privatize hospitals. Further, Buor and Bream (2004) find that gross domestic product per capita and public health expenditures are related to lower levels of maternal mortality in Sub-Saharan Africa. Alvarez, Gil, and Hernandez (2009) find that female educational attainment corresponds with lower maternal mortality in the Sub-Saharan Africa.

This research serves as the starting point for our study. However, we seek to address an important gap in the literature. There is little cross-national literature that examines the relationship among maternal and neo-natal mortality and access to an improved water source and improved sanitation facility in SubSaharan Africa. This is somewhat surprising because the region has the lowest percentage of population with access to an improved water source $(66 \%)$ and improved sanitation facility (32\%) (World Bank, 2015). Further, a lack of clean water and basic sanitation facilities can impact pregnant women in several ways. First, they may contract illnesses that either kill them directly or weaken their immune systems, leading to complications during pregnancy (Benova, Cumming, \& Campbell, 2014). Second, pregnant women who habitually travel long distances to collect water often experience weight loss and issues during birth (Dankelman \& Davidson, 2008). Third, a lack of clean water and sanitation prevents essential hygiene practices - including hand washing by birth attendants, delivering the infant on a clean surface, sterilizing equipment for cord cutting, and providing clean blankets - which can lead to sepsis, tetanus and, ultimately, death (Blencowe, Cousens, \& Mullany, 2011). Fourth, clean 
water and adequate sanitation are necessary to treat mothers and infants for complications following delivery (Mamaye, 2015). We elaborate upon these factors in detail below.

Thus, we seek to expand upon existing cross-national research here by testing the hypothesis that having access to an improved water source and an improved sanitation facility should lower maternal mortality and neo-natal mortality in Sub-Saharan Africa. We do so by analyzing cross-national data using two-way fixed effects models for a sample of 32 Sub-Saharan African nations from 1990 to 2005. We now turn to a detailed discussion of how access to clean water and basic sanitation may impact maternal and neo-natal mortality. We go on to describe the variables used in the analysis, our methodology, and the findings. We conclude by summarizing the findings, discussing the theoretical and methodological implications, offering some policy suggestions, and suggesting possible directions for future research.

\section{Water, sanitation, and health in Sub-Saharan Africa}

The lack of access to clean water and basic sanitation may contribute to increased maternal and neo-natal mortality at three different points. First, it may affect the health of the woman and the fetus during the pregnancy. When a pregnant woman drinks polluted water, she is exposed to a host of bacterial, viral, and parasitic infections (Benova, Cumming, \& Campbell, 2014). In many instances, women contract various diarrheal diseases including dysentery, cholera, or typhoid. These diseases may directly kill a woman or weaken her immune system, which leads to complications during birth (Save the Children, 2014). Certain diseases, like Hepatitis E, are more commonly transmitted when a community lacks access to basic sanitation facilities. Such waterborne diseases tend to have more severe consequences for pregnant women than for the broader population (Mamaye, 2015). Pregnant women are both more susceptible to and more severely affected by diseases due changes in the immune system while adapting to the new fetus (Jamieson, Theison, \& Rasmussen, 2006). Additionally, inadequate sanitation leads to the transmission of intestinal nematode infections. In Sub-Saharan Africa, hookworm infects nearly 44 million pregnant women annually, which increases their risk of anemia and, as a result, severe bleeding during birth (World Health Organization, 1996). There are also instances of chemicals from industry, agriculture, and mining contaminating water sources (Mamaye, 2015). For example, arsenic used in mining is also known to increase the risk of anemia (Vahter, 2009). Further, certain agricultural practices increase 
levels of salt in drinking water, leading to increased risk of hypertension and pre-eclampsia in pregnant women, factors associated with maternal mortality (Mameye, 2015). These factors also contribute to neo-natal mortality. The diseases are passed from the mother to the fetus in utero, leading to weakened immune systems, early births, complicated births, and possibly death.

Further, maternal and neo-natal mortality may be exacerbated by poor access to water. In many Sub-Saharan African nations, women are tasked with collecting water for household tasks like cooking, cleaning, and bathing (Shandra, Shandra, \& London, 2008). When women must travel longer distances or spend more hours collecting water, they tend to collect less water (Dankelman \& Davidson, 1988). This has implications for household and personal hygiene with disproportionate consequences for pregnant women, who are more vulnerable to water- and sanitation-related diseases (Howard \& Batram, 2003). It also increases the possibility that such diseases will be passed along during the pregnancy. At the same time, walking long distances over extended periods of time to fetch water adversely affects a woman's weight gain during pregnancy, thereby leading to complications during birth for both the mother and child (Mamaye, 2015).

Second, a lack of clean water and basic sanitation also leads to women and infants dying during or immediately after delivery. A recent study drawing on a sample of 56 low-income nations estimates that only $38 \%$ of hospitals have access to an improved water source and only $19 \%$ have access to adequate sanitation (World Health Organization, 2015). Approximately 35\% do not provide soap and water for staff and patients to wash their hands (World Health Organization, 2015).

These statistics have real implications for pregnant women and newly born infants because it means that hygiene practices essential for safe deliveries are not being carried out in many Sub-Saharan African nations (Yardley, 2010). Thus, women are at a higher risk of getting infections and dying from diseases like sepsis if clean water and adequate sanitation are lacking (World Health Organization, 2015). Further, there are implications for newborns because they are even more vulnerable to life-threatening infections like sepsis and tetanus shortly after birth. It is estimated that between $30 \%$ and $40 \%$ of the infections resulting in sepsis-related deaths are transmitted from mother to child at the time of birth (Blencowe, Cousens, and Mullany, 2011). After delivery, women need running water and working toilets for personal hygiene and to bathe infants, which further limits the spread of infections and diseases (Mamaye, 2015). Running water is also essential to treat pregnancy-related complications like obstetric fistula and perineum rupture among women, and diarrheal diseases among newly born infants (Cotingham \& Royston, 1991). These issues are even 
more pronounced for women who give birth at home, because less than $2 \%$ have access to clean water and basic sanitation in their homes (World Health Organization, 2015).

Third, lack of clean water and basic sanitation has the potential to affect women and newly born infants in the months following delivery and beyond. Access to adequate water and sanitation is key to good menstrual hygiene, which prevents subsequent infections in both mothers and their children (Shordt, Smet, \& Herschderfer, 2012). For instance, repeated diarrheal or intestinal nematode infections contribute to women and children becoming malnourished. This may contribute directly to neo-natal mortality. For women, it translates into being underweight, which has the potential to complicate future pregnancies (Shordt, Smet, \& Herschderfer, 2012). Malnutrition also means women and infants are more vulnerable to other infectious diseases (e.g., malaria, tuberculosis, polio) that can lead to death (Rice, 2008). Finally, clean water is crucial for mothers who do not breastfeed, to ensure that formula is safe for consumption (Save the Children, 2014).

The preceding discussion suggests that lacking access to clean drinking water and basic sanitation adversely affects pregnant women and newly born infants in Sub-Saharan African nations. Thus, we expect that access to an improved water source and an improved sanitation facility should correspond with decreased maternal and neo-natal mortality. However, we need to consider a number of other important predictors when testing this hypothesis. This is because there may be structural barriers that hinder the provision of water and sanitation facilities, inhibit accessibility, or limit opportunities for their use in hygienic practices. These variables include structural adjustment, debt service, foreign investment, gross domestic product, domestic investment, female educational attainment, democracy, public health expenditures, conflict, and human immunodeficiency virus prevalence.

\section{Dependent variable}

\section{Maternal mortality ratio}

The dependent variable in our study is the maternal mortality ratio for a Sub-Saharan African nation. This variable measures the annual number of deaths from pregnancy-related causes per 100,000 live births. A maternal death is defined as the death of a woman while pregnant or within 42 days of the termination of a pregnancy from any cause related to or aggravated by pregnancy (World Health Organization, 2010). We take the square root of the ratio to correct for its skewed distribution. The data are available for 1990, 
1995, 2000, and 2005. We obtained the data online from the United Nation's Millennium Development Goals portal. All other data may be obtained online from the World Bank's World Development Indicators unless otherwise noted. The descriptive statistics and bivariate correlations for the variables used in this analysis are contained in Table 1 .

Table 1(a). Univariate descriptive statistics and bivariate correlations for variables in the analysis

\begin{tabular}{|c|c|c|c|c|c|}
\hline Variable & $\mathrm{n}$ & Mean & S.D. & Min. & Max. \\
\hline Maternal mortality (per 100,000 live births)* & 72 & 25.50 & 6.19 & 5.29 & 36.06 \\
\hline Neo-natal mortality (per 1,000 live births) $†$ & 72 & 3.64 & 0.30 & 2.29 & 4.08 \\
\hline IMF structural adjustment ( 1 = yes) & 72 & 0.67 & 0.47 & 0 & 1 \\
\hline Access to improved sanitation $\dagger$ & 72 & 3.17 & 0.74 & 1.39 & 4.54 \\
\hline Access to improved water source $\dagger$ & 72 & 4.04 & 0.30 & 3.00 & 4.61 \\
\hline Female secondary school enrollments & 72 & 20.83 & 17.10 & 4.00 & 87.00 \\
\hline Multilateral debt service† & 72 & 2.50 & 0.81 & 0.45 & 3.77 \\
\hline Multinational corporate investment $†$ & 72 & 2.29 & 1.12 & -1.05 & 4.81 \\
\hline Domestic investment† & 72 & 2.94 & 0.30 & 1.90 & 3.68 \\
\hline Gross Domestic Product per capita† & 72 & 5.86 & 0.80 & 4.65 & 8.39 \\
\hline Democracy & 72 & 4.64 & 1.46 & 1 & 7 \\
\hline Public health expenditures $\dagger$ & 72 & 0.62 & 0.45 & -0.78 & 1.41 \\
\hline Human immunodeficiency virus prevalence & 72 & 4.36 & 5.54 & 0.10 & 26.40 \\
\hline Year $=1990$ & 72 & 0.22 & 0.42 & 0 & 1 \\
\hline Year $=1995$ & 72 & 0.31 & 0.46 & 0 & 1 \\
\hline Year $=2000$ & 72 & 0.29 & 0.46 & 0 & 1 \\
\hline Year = 2005 & 72 & 0.18 & 0.39 & 0 & 1 \\
\hline No conflict & 72 & 0.81 & 0.40 & 0 & 1 \\
\hline Minor conflict intensity & 72 & 0.03 & 0.17 & 0 & 1 \\
\hline Intermediate conflict intensity & 72 & 0.06 & 0.23 & 0 & 1 \\
\hline High conflict intensity (war) & 72 & 0.11 & 0.32 & 0 & 1 \\
\hline
\end{tabular}

Notes: * indicates data transformed using square root and † indicates data transformed using the natural logarithm

See text for data sources. 


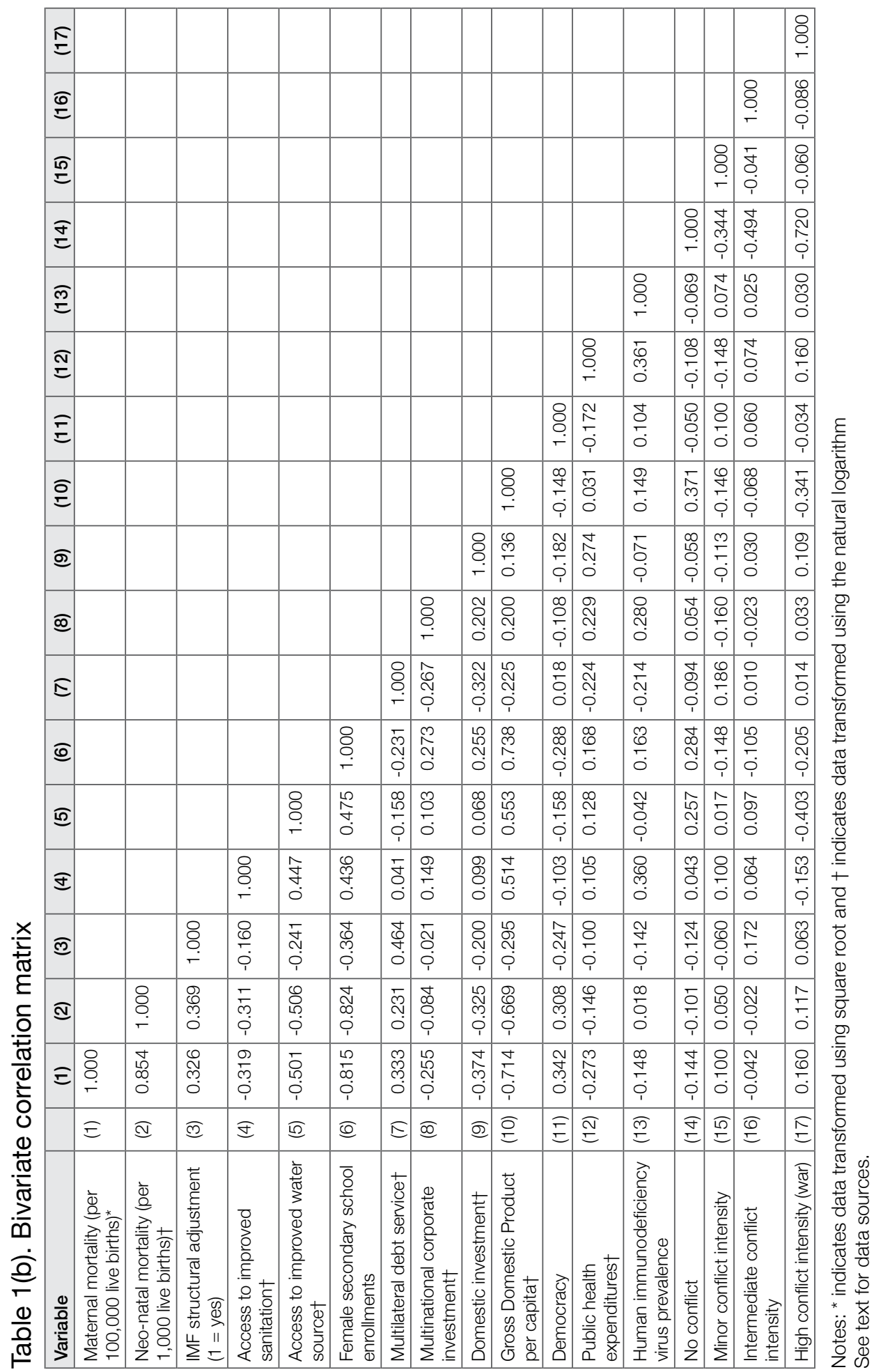




\section{Neo-natal mortality ratio}

We also analyze the neo-natal mortality ratio because the health of a mother is closely linked to the health of her newly born infant in the first month (World Health Organization, 2015). This variable measures the number of infant deaths before 28 days of age for every 1,000 live births in the specified year (World Bank, 2015). We log this measure to correct for its skewed distribution.

\section{Main independent variables}

\section{Access to an improved water source}

This variable measures the percentage of the country's population who has access to an improved water source. According to the United Nations (2010), an improved water source includes any of the following types of water sources: household connections, public standpipes, boreholes, protected dug wells, protected springs, and rainwater collection. An unimproved water source may include an unprotected well, surface water, vendor provided water, tanker provided water, and bottled water. We log this variable to correct for its skewed distribution. We hypothesize that higher levels of access to an improved drinking water source should be related to decreased maternal and neo-natal mortality within Sub-Saharan African nations.

\section{Access to an improved sanitation facility}

We also include the percentage of a population who has access to an improved sanitation facility in the models. The United Nations (2010) considers an improved sanitation facility to be a connection to a public sewer, connection to a septic tank, pour flush latrine, simple pit latrine, ventilated pit latrine, pit latrine with slab, and composting toilet. An unimproved sanitation facility includes an open pit latrine, public latrines, buckets, latrines, hanging latrines, flush to elsewhere (e.g., street, yard, river, ditch, etc.), and no facility (United Nations, 2010). This variable is logged to correct for its skewed distribution. We expect that higher levels of access to an improved sanitation facility should correspond to lower maternal and neo-natal mortality within a Sub-Saharan African nation. 


\section{Other relevant independent variables}

\section{International Monetary Fund structural adjustment loan recipient}

This is a dummy variable where we code Sub-Saharan African nations that are under an International Monetary Fund structural adjustment loan at least one year prior to 1990, 1995, 2000, and 2005 with a value of one. All other Sub-Saharan African nations serve as the reference category and are coded with a value of zero. These data may be obtained from International Monetary Fund's online lending database. We hypothesize that when a Sub-Saharan Africa nation is under an International Monetary Fund structural adjustment loan then it should have higher maternal and neo-natal mortality than when the country is not under such a loan. This is because the International Monetary Fund tends to require nations to cut government spending for health and sell off government assets like hospitals (Peet, 1999).

\section{Debt service ratio}

In addition to the pressure to adopt macro-economic policy reforms under structural adjustment, poor nations must continually service their foreign debts. Clearly, it is also important to control for debt service as well as structural adjustment (Bradshaw \& Schafer, 2000). Thus, we include the repayment of long-term debt. The data are measured as a percentage of exports of goods and services and, as a result, provides a measure of debt repayment relative to its earnings. This variable is logged to correct its skewed distribution. We hypothesize that higher levels of debt service should be associated with more maternal and neo-natal mortality within Sub-Saharan African nations because it removes resources available for governmental investment in health, family planning, and reproductive services.

\section{Multinational corporate investment}

We include the stock measure of multinational corporate investment in the models because structural adjustment loans often require that indebted nations liberalize trade for foreign investors (Jorgenson, Dick, \& Mahutga, 2008). These data may be obtained online from the United Nations Conference on Trade and Development statistical portal. We log this variable to correct for its skewed distribution. We expect that higher levels of multinational corporate investment should be associated with higher maternal and neo-natal mortality in a Sub-Saharan African nation. As noted above, there are several reasons why this may be the case, especially foreign corporations expatriating the majority of their profits (Frey \& Field, 2000). 


\section{Gross domestic product}

As is standard in such analyses, it is necessary to take into account a nation's level of development in order to make sure any effects are independent of a nation's level of wealth (London \& Ross, 1995). In this regard, we employ a measure of gross domestic product per capita at purchasing power parity. We log this variable because of its highly skewed distribution. We expect that higher levels of gross domestic product per capita should correspond with less maternal and neo-natal mortality within Sub-Saharan African nations. This is because higher levels of wealth tend to bring higher standards of living, advanced medical technology, and demographic changes that improve health (Shen \& Williamson, 1999).

\section{Domestic investment}

We also include a measure of domestic investment, known as gross capital formation, as a percentage of gross domestic product. It is standard to control for this variable when considering the impact of foreign investment. We log domestic investment to correct for its skewed distribution. We hypothesize that higher levels of domestic investment should be associated with lower maternal and neo-natal mortality in Sub-Saharan Africa. This is most likely the case because domestic investment increases capital available for government funding for health, education, family planning, and nutrition (Rice, 2008).

\section{Female secondary school enrollment}

We use gross female secondary school enrollments as an indicator of educational attainment. These data come from the World Bank's World Development Indicators (2005). We hypothesize that higher levels of female secondary school enrollment should be related to decreased maternal and neo-natal mortality in Sub-Saharan Africa. This may well be because secondary education for women is associated with wider use of health services, especially prenatal care. Secondary education may reduce maternal marriage, which is also associated with better reproductive health (Gupta, 2004; Malhortra, 2011). This is because when women are married very young, they tend have less control over health decisions (Gupta, 2004). Secondary education also tends to improve access to information about nutrition, birth spacing, reproductive health, and immunizations (Filmer \& Pritchett, 1999). Further, educating girls also leads to higher economic growth, and ultimately, higher living standards (Rice, 2008). 


\section{Democracy}

We use the average of Freedom House's political rights and civil liberties scales to measure the level of democracy within a nation. The data may be obtained online from Freedom House. According to Freedom House (2005), political rights refer to the degree to which a nation is governed by democratically elected representatives and has fair, open, and inclusive elections. The civil liberties scale measures the levels of freedom of press, freedom of assembly, general personal freedom, freedom of private organizations, and freedom of private property within a nation (Freedom House, 2005). The variables have the following coding: free (1-2), partially free (3-5), and not free (6-7). We hypothesize that higher levels of repression should correspond with increased maternal and neo-natal mortality in Sub-Saharan Africa. This is most likely the case because freely elected and open governments respond to popular demands for health services (especially for women) due to political activism and electoral accountability, while repressive governments do not (Wickrama \& Mulford, 1996).

\section{Public health expenditures}

It is also important to control for the general provisioning of public health services in a cross-national study like this (Shen \& Williamson, 1999). In this regard, we include a measure of the fiscal capacity of a nation by including public health expenditures as a percentage of gross national product in the models. This measure includes all current expenditures by all levels of government for the provision of medical services. These data may be obtained from the World Bank's (2005) World Development Indicators. We expect higher levels of public health expenditures to be related to lower maternal and neo-natal mortality within a Sub-Saharan African nation. This is because government investment in hospitals and primary care (e.g., immunizations, family planning, prenatal care, postnatal care, and nutrition counseling) should improve health (Moon \& Dixon, 1985).

\section{Conflict intensity}

We also want to control for the impact of conflict intensity within a SubSaharan African nation in a given year. We create three dummy variables and include them in the analysis. The data and coding come from Wallensteen, Sollenburg, and Erickson (2005). The first dummy variable captures minor conflict intensity, which is defined as less than 25 battle deaths in a given year. The second dummy variable measures an intermediate level of conflict intensity of more than 25 battle deaths in a given year and a historical total of more than 1,000 battle deaths. The third dummy variable captures high-conflict intensity and involves more than 1,000 battle deaths in the specified year. The reference category indicates that a Sub-Saharan African nation is not experiencing any conflict and is coded with a value of zero. We expect that nations experiencing 
conflicts should have higher maternal and neo-natal mortality because conflict often disrupts the delivery of health services within a nation (Scanlan, Jenkins, \& Petersen, 2007).

\section{Human immunodeficiency virus prevalence}

We also include the prevalence of HIV for each Sub-Saharan African nation. This variable measures the percentage of a country's population ages 15-49 that is infected with HIV and alive at the end of the year specified, regardless of whether they have developed symptoms of acquired immune deficiency syndrome or not. We hypothesize that higher levels of HIV prevalence should be associated with greater maternal and neo-natal mortality. This is because women may experience opportunistic infections (e.g., tuberculosis, pneumonia, and malaria) due to weakened immune systems, which could lead to mortality of them or their infants (Foster \& Williamson, 2000). There are also indirect effects. When mothers fall sick from the disease or die from associated illnesses, children assume the burden of earning money. In general, there are fewer resources (e.g., food, water, etc.) available for the family because children tend to earn less than adults (Scanlan, 2010). This also removes children, especially girls, from school, thereby eroding any potential gains in lowering maternal and neo-natal mortality via educational attainment (Scanlan, 2010).

\section{Methodology}

We estimate a two-way fixed effects regression model with robust standard errors clustered by country to examine the effect of access to an improved water source and sanitation facility within Sub-Saharan African nations. This is one of the most commonly used models by social scientists to deal with potential problems of heterogeneity bias (Halaby, 2004). The issue of heterogeneity bias refers to the impact of unmeasured time-invariant variables that are omitted from a regression model. To deal with heterogeneity bias, fixed effects models control for omitted variables that are time invariant but do not vary across cases. This is done by estimating unit-specific intercepts, which are the fixed effects for each case. This approach is appropriate for cross-national analysis because time-invariant unmeasured factors (e.g., climate, geography, etc.) can affect maternal and neo-natal mortality in Sub-Saharan Africa. Thus, a fixed effects approach should provide a stringent assessment of the relationship among the independent and dependent variables because the associations between the variables are the estimated net of unmeasured between-country effects (Brady, Kaya, \& Beckfield, 2007). Generally, this modeling strategy is robust against missing control variables (Hsiao, 2003). Post-estimation regression diagnostics indicate no violation of this assumption. 
The notation for the two-way fixed effects model is as follows:

$$
\mathrm{y}_{i t}=\mathrm{a}+\mathrm{B}_{1} \mathrm{x}_{i t 1}+\mathrm{B}_{2} \mathrm{x}_{i t 2}+\ldots+\mathrm{B}_{k} \mathrm{x}_{i t k}+\mathrm{u}_{i}+\mathrm{w}_{t}+\mathrm{e}_{i t^{\prime}}
$$

where

$i=$ each country in the analysis,

$t=$ each time period in the analysis,

$y_{i t}=$ dependent variable for each country at each time period,

$a=$ the constant,

$B_{1}$ to $B_{k}=$ coefficients for each independent variables,

$x_{i t k}=$ independent variables for each country at each time point,

$u_{i}=$ country-specific disturbance terms that are constant over time,

$w_{t}=$ period-specific disturbance terms that are constant across all countries,

and

$e_{i t}=$ disturbance terms specific to each country at each time point.

To determine if the two-way fixed effects model is more appropriate than the random effects estimator, we calculate Sargan-Hansen test statistics for each model. The coefficients for these $\chi 2$ tests reach a level of statistical significance for every model, indicating that the fixed effects estimator is more efficient than the random-effects estimator. This is because the country-specific error terms are correlated with the independent variables included in the models (Baum, 2006), whereas the random-effects estimator assumes that this correlation is zero.

\section{Findings}

In Table 2, we present the two-way fixed effects regression estimates of maternal and neo-natal mortality in Sub-Saharan Africa. ${ }^{2}$ In every equation, we include structural adjustment, debt service, foreign investment, gross domestic product, domestic investment, female secondary school enrollments, democracy, level of conflict, public health expenditures, and human immunodeficiency virus prevalence. In equations 2.1 and 2.2 , we examine the

2 The following 32 Sub-Saharan African nations are included in the analysis. They are: Burkina Faso (1990, 2000), Burundi (1990, 2005), Cameroon (1990, 1995), Comoros (1990, 1995), Congo (2000), Côte d'Ivoire (1990, 1995, 2000), Eritrea (2000), Ethiopia (1995, 2000, 2005), Gabon (1995), Gambia (1995, 2005), Ghana (1990, 1995, 2000, 2005), Guinea (1990, 1995, 2000), Kenya (1990, 1995, 2000, 2005), Madagascar (2005), Malawi (1995, 2000), Mali (1990, 1995, 2000), Mauritania (1995), Mauritius (1995, 2000, 2005), Mozambique (1995, 2000, 2005), Niger (1995, 2000), Nigeria (1990, 2000, 2005), Rwanda (1990, 2000, 2005), Senegal (1990, 1995 , 2000), Sudan (1990, 1995, 2005), Swaziland (1995, 2000, 2005), Tanzania (1990, 1995), Togo (1990, 1995, 2000), Uganda (1995, 2000, 2005), Zambia (2000), Zimbabwe (1990). 
determinants of maternal mortality. In equations 2.3 and 2.4, we examine the causes of neo-natal mortality. In odd-numbered equations, we include access to an improved water source. In even-numbered equations, we include access to an improved sanitation facility.

Table 2. Two-way fixed effects regression estimates of maternal mortality and neo-natal mortality in Sub-Saharan Africa, 1990-2005

\begin{tabular}{|c|c|c|c|c|}
\hline & Eq. 2.1 & Eq. 2.2 & Eq. 2.3 & Eq. 2.4 \\
\hline & Maternal & Maternal & Neo-Natal & Neo-Natal \\
\hline \multirow[t]{3}{*}{ Access to improved water } & $-4.182^{\star \star}$ & & $-0.104^{\star}$ & \\
\hline & -0.200 & & -0.103 & \\
\hline & (1.279) & & $(0.054)$ & \\
\hline \multirow[t]{3}{*}{ Access to improved sanitation } & & $-4.676^{\star \star \star}$ & & $-0.108^{\star \star}$ \\
\hline & & -0.561 & & -0.266 \\
\hline & & (1.315) & & $(0.036)$ \\
\hline \multirow{3}{*}{$\begin{array}{l}\text { IMF structural adjustment } \\
(1 \text { = yes) }\end{array}$} & $1.079^{\star \star}$ & $1.172^{\star \star \star}$ & $0.024^{*}$ & $0.022^{*}$ \\
\hline & 0.083 & 0.090 & 0.038 & 0.035 \\
\hline & $(0.329)$ & (0.338) & $(0.012)$ & $(0.012)$ \\
\hline \multirow[t]{3}{*}{ Debt service } & 0.379 & 0.437 & 0.027 & 0.028 \\
\hline & 0.050 & 0.057 & 0.072 & 0.076 \\
\hline & $(0.583)$ & $(0.546)$ & $(0.019)$ & $(0.018)$ \\
\hline \multirow[t]{3}{*}{ Multinational corporate investment } & $0.738^{*}$ & $0.800^{\star *}$ & 0.017 & 0.018 \\
\hline & 0.133 & 0.144 & 0.064 & 0.068 \\
\hline & $(0.354)$ & $(0.312)$ & $(0.014)$ & $(0.013)$ \\
\hline \multirow[t]{3}{*}{ Domestic investment } & -1.570 & -0.962 & 0.007 & 0.020 \\
\hline & -0.075 & -0.046 & 0.007 & 0.020 \\
\hline & $(1.116)$ & $(0.981)$ & $(0.025)$ & $(0.027)$ \\
\hline \multirow[t]{3}{*}{ GDP per capita } & $-9.256^{\star \star}$ & $-8.779^{\star \star \star}$ & $-0.343^{\star \star \star}$ & $-0.331^{\star \star \star}$ \\
\hline & -1.195 & -1.134 & -0.913 & -0.881 \\
\hline & (2.934) & (2.236) & $(0.077)$ & (0.066) \\
\hline \multirow[t]{3}{*}{ Female secondary school enrollment } & $-0.299^{\star \star \star}$ & $-0.278^{\star \star}$ & $-0.009^{\star \star}$ & $-0.008^{\star \star}$ \\
\hline & -0.827 & -0.767 & -0.491 & -0.459 \\
\hline & $(0.082)$ & $(0.083)$ & $(0.003)$ & $(0.003)$ \\
\hline \multirow[t]{3}{*}{ Democracy } & -0.287 & -0.299 & $-0.016^{\star}$ & $-0.016^{\star}$ \\
\hline & -0.068 & -0.071 & -0.077 & -0.077 \\
\hline & $(0.300)$ & $(0.281)$ & $(0.009)$ & $(0.008)$ \\
\hline \multirow[t]{3}{*}{ Public health expenditures } & 0.355 & 0.372 & $0.043^{\star *}$ & $0.042^{\star \star}$ \\
\hline & 0.026 & 0.027 & 0.065 & 0.063 \\
\hline & $(0.758)$ & $(0.685)$ & $(0.017)$ & $(0.015)$ \\
\hline
\end{tabular}




\begin{tabular}{|c|c|c|c|c|}
\hline & Eq. 2.1 & Eq. 2.2 & Eq. 2.3 & Eq. 2.4 \\
\hline & Maternal & Maternal & Neo-Natal & Neo-Natal \\
\hline \multirow{3}{*}{$\begin{array}{l}\text { Minor conflict intensity } \\
(1=\text { yes })\end{array}$} & -0.591 & $-1.118^{*}$ & 0.049 & 0.039 \\
\hline & -0.016 & -0.030 & 0.027 & 0.021 \\
\hline & $(0.843)$ & $(0.572)$ & $(0.045)$ & $(0.032)$ \\
\hline \multirow{3}{*}{$\begin{array}{l}\text { Intermediate conflict intensity } \\
(1=\text { yes })\end{array}$} & $-1.829^{\star}$ & $-2.251^{\star \star}$ & 0.048 & 0.041 \\
\hline & -0.068 & -0.084 & 0.037 & 0.031 \\
\hline & $(0.843)$ & $(0.853)$ & $(0.038)$ & $(0.036)$ \\
\hline \multirow{3}{*}{$\begin{array}{l}\text { High conflict intensity (war) } \\
\text { (1 = yes) }\end{array}$} & $-8.392^{\star \star \star}$ & $-8.653^{\star \star \star}$ & $-0.187^{\star \star}$ & $-0.190^{\star \star \star}$ \\
\hline & -0.429 & -0.442 & -0.197 & -0.200 \\
\hline & $(1.527)$ & (1.655) & $(0.055)$ & $(0.052)$ \\
\hline \multirow[t]{3}{*}{ HIV prevalence } & 0.069 & 0.127 & 0.003 & 0.004 \\
\hline & 0.061 & 0.114 & 0.055 & 0.081 \\
\hline & $(0.084)$ & $(0.082)$ & (0.003) & $(0.003)$ \\
\hline \multirow[t]{3}{*}{ Year = 1995} & $-1.054^{*}$ & $-1.153^{\star *}$ & $-0.042^{\star *}$ & $-0.044^{\star *}$ \\
\hline & -0.079 & -0.086 & -0.064 & -0.068 \\
\hline & $(0.490)$ & $(0.423)$ & $(0.014)$ & $(0.015)$ \\
\hline \multirow[t]{3}{*}{ Year $=2000$} & 0.112 & -0.219 & -0.040 & $-0.049^{*}$ \\
\hline & 0.008 & -0.016 & -0.061 & -0.075 \\
\hline & $(1.021)$ & $(1.005)$ & (0.024) & $(0.026)$ \\
\hline \multirow[t]{3}{*}{ Year $=2005$} & $3.313^{*}$ & 2.841 & -0.041 & -0.054 \\
\hline & 0.207 & 0.178 & -0.053 & -0.070 \\
\hline & $(1.891)$ & (1.902) & (0.059) & (0.063) \\
\hline \multirow[t]{2}{*}{ Constant } & $105.733^{\star \star \star}$ & $98.357^{\star \star \star}$ & $6.197^{\star \star \star}$ & $5.987^{\star \star \star}$ \\
\hline & (19.003) & $(17.477)$ & $(0.531)$ & $(0.400)$ \\
\hline Sargan-Hansan test statistic & $95.279^{\star \star \star}$ & $336.087^{\star \star \star}$ & $157.279^{\star \star \star}$ & $94.845^{\star \star \star}$ \\
\hline Observations (N) & 72 & 72 & 72 & 72 \\
\hline Countries & 31 & 31 & 31 & 31 \\
\hline Within R square & 0.761 & 0.779 & 0.905 & 0.909 \\
\hline Overall $\mathrm{R}$ square & 0.664 & 0.576 & 0.618 & 0.576 \\
\hline
\end{tabular}

Notes:

- ${ }^{\star} \mathrm{p}<.05,{ }^{\star \star} \mathrm{p}<.01,{ }^{\star \star *} \mathrm{p}<.001$ for a one-tailed test.

- The first number is the unstandardized regression coefficient, the second number is the standardized regression coefficient, and the third number in parentheses is the robust standard error.

- The null hypothesis for the Sargan-Hansen test is that the random effects estimator is more efficient than the fixed effects estimator.

- The reference category for conflict intensity is no conflict in a country. The reference category for the IMF variable is no loan. 
We begin with a discussion of the water and sanitation variables. In equation 2.1 , we find that access to an improved water source is associated with less maternal mortality. The coefficient for this variable is negative and statistically significant. In equation 2.2, we find that access to an improved sanitation facility also reduces maternal mortality. The coefficient is also negative and statistically significant. We find a similar pattern for neo-natal mortality as well. In equations 2.3 and 2.4, the coefficients for access to an improved water source and sanitation facility are negative and significant. Taken together, the findings indicate the importance of water and sanitation in improving maternal and neonatal health in Sub-Saharan Africa.

It is important to note other factors that explain maternal and neo-natal mortality in Sub-Saharan Africa. First, we find that when a Sub-Saharan African nation is under an International Monetary Fund structural adjustment loan, it tends to have higher maternal and neo-natal mortality. The coefficients for this variable are positive and significant in all four equations of Table 2. Second, we find that higher levels of gross domestic product per capita are associated with lower maternal and neo-natal mortality within Sub-Saharan African nations. The coefficients for this variable are negative and significant in every equation. ${ }^{3}$ Third, we find that higher levels of female secondary school enrollments are associated with lower maternal and neo-natal mortality within Sub-Saharan African nations. The coefficients for this variable are negative and significant in all four equations. Fourth, we find that the intensity of a conflict is associated with decreased maternal and neo-natal mortality. The coefficients are negative and significant for the highest-intensity conflict dummy variable. This finding contradicts our hypothesis from above. However, it may be that high-intensity conflicts are only taking place in a portion of a Sub-Saharan African nation away from major population centers, thereby limiting disruptions to health services. We also note that the coding of this variable means that a negative coefficient indicates that when intensive conflict ends, maternal and neo-natal mortality are subsequently higher. This interpretation is consistent with the suggestion that conflict disrupts health services.

There are also some non-significant or non-consistent findings that merit comment. First, we do not find that debt repayment is associated with increased maternal or neo-natal mortality. Second, we find that domestic investment does not explain any significant variation in either dependent variable. Third, we do not find that HIV prevalence is related to maternal and neo-natal mortality in Sub-Saharan Africa. The coefficients for all of these variables fail to reach a level of statistical significance in Table 2. Fourth, the effects of democracy and public health expenditures are inconsistent and not in the expected direction.

3 We would like to control for the level of economic inequality within a nation. However, comparable data are not available for a large number of Sub-Saharan African nations across time from the World Bank (2015). 
We find that democracy and public health expenditures are associated with increased neo-natal mortality but not maternal mortality. In equations 2.3 and 2.4, the coefficients are positive and significant. Fifth, we find that multinational corporate investment is related to increased maternal mortality but not neonatal mortality. The coefficients for this variable are positive and significant in the maternal mortality models.

\section{Discussion and conclusion}

Sub-Saharan Africa has the highest maternal and neo-natal mortality rates in the world (World Bank, 2015). There have been several cross-national studies that have attempted to explain why this may be the case (Pandolfelli, Shandra, \& Tyagi, 2014; Alvarez, Gil, \& Hernandez, 2009; Buor \& Bream, 2004). These authors find that several factors including structural adjustment, gross domestic product per capita, public health expenditures, and female education can affect maternal mortality. These findings serve as the starting point of our study.

We expand upon this work in a novel way. There has been no research to our knowledge that examines if access to an improved water source and sanitation facility influences maternal and neo-natal mortality rates in Sub-Saharan Africa. We begin to address this gap in the cross-national literature here and find that access to clean water and basic sanitation correspond with less maternal and neo-natal mortality in Sub-Saharan Africa. The coefficients for both variables are negative and significant across Table 2.

We also find that a number of other factors are related to maternal and neo-natal mortality. First, we find that International Monetary Fund structural adjustment is associated with increases in maternal and neo-natal mortality. Second, we find that gross domestic product per capita is associated with decreased maternal and neo-natal mortality. Third, the results indicate that higher levels of female secondary education correspond with lower maternal and neo-natal mortality.

There are some important theoretical insights that emerge from the findings. In general, there has been a lack of cross-national research addressing how the natural environment affects health and well-being (see Mazur \& Rosa, 1974, who examined the decoupling between energy consumption and quality of life, as an early notable exception). However, this has begun to change in the past few years. For example, Dietz, Rosa, and York (2009) examine how life expectancy for nations is a function of their natural, physical, and human capital, and Jorgenson (2014) examines the impact of gross domestic product per capita on the ratio of life expectancy to carbon dioxide emissions or the carbon intensity of well-being. 
Nevertheless, consideration of the impact of access to water and basic sanitation on health in cross-national research remains nascent at best. A review of the literature revealed eight cross-national studies appearing in peer-reviewed journals that considered water and sanitation (Burroway, 2010; Cairncross et al., 2010; Cheng et al., 2012; Chowdhury, Islam, \& Hossain, 2010; Handa, Koch, \& Ng, 2010; Prüss et al., 2002; Rutstein, 2000; Shandra, Shandra, \& London, 2011). However, none examine the effects on neo-natal mortality in Sub-Saharan Africa. This is somewhat surprising because a lack of access to water and basic sanitation contributes to diarrheal diseases and other infections that kill women and infants directly or lead to complications at various points of pregnancy that put their lives at risk (World Health Organization, 2015). Thus, we argue that it is imperative to consider water and sanitation among other environmental factors in cross-national research because the welfare of women and infants is inextricably linked to the state of the natural environment. Pregnant women are more susceptible to disease due to weakened immune systems (Jamieson et al., 2006). Many such diseases are waterborne or water-transmitted and easily prevented by increasing access to clean water and sanitation. However, such factors only explain part of each phenomenon. There are "external" (i.e., structural adjustment) and "internal" (i.e., female educational attainment) factors that are essential to understanding how to curb maternal and neo-natal mortality rates in Sub-Saharan Africa. Our findings indicate that it is only when researchers consider such factors simultaneously that they will arrive at the most comprehensive understanding of reproductive health.

We can offer some methodological implications that correspond with the theoretical insights. It is typical for cross-national research to include dummy variables for the region of the world in which a country is located as independent variables in a model (Shandra, 2007). This helps control for findings that may arise out of geographical and historical circumstances, which cannot be accounted for by the other independent variables in the model. There are often statistically significant differences among the regions of the world in the dependent variable under examination. The authors often hypothesize why such differences exist or offer no reason for why such a relationship exists. For example, Scanlan (2010) finds that nations in Sub-Saharan Africa tend to have higher levels of child mortality than nations in other regions of the world. The author hypothesizes that this may be the case because Sub-Saharan African nations tend to have a higher prevalence of HIV (Scanlan, 2010). However, the author does not test this hypothesis. Scanlan (2010) analyzes a cross-national sample of less industrialized countries yet reiterates the need for multiple analyses, including regional analyses. We begin to address this gap by examining the factors that are associated with maternal and neo-natal mortality in only Sub-Saharan Africa. Our analysis allows us to examine within a specific region the factors associated with higher or lower maternal and neo-natal mortality, 
rather than just speculate about why such relationships exist. We further refine previous research by controlling for all stable between-country variation and therefore avoid problems of comparing across such diverse countries in Sub-Saharan Africa.

There are some policy recommendations that follow from our findings. Given that International Monetary Fund structural adjustment adversely affects mothers and infants in Sub-Saharan Africa, we argue that non-governmental organizations, social movements, and concerned citizens should lobby officials at this institution to change or eliminate these policies. Some changes may include eliminating certain macroeconomic policy reforms, especially privatization of government assets, and user fees, which often limit not only access to health services but also to water and sanitation (Rich, 1994).

It is also important to support policy initiatives that increase women's education. Although female education tends to correspond with higher earnings for women, increased economic growth, and augmented standards of living, there are other notable benefits relevant to maternal and neo-natal well-being. In particular, educated women tend to be more knowledgeable about disease causation, more likely to utilize health services, more willing to travel outside of the community to access health care, more adept at interacting with health professionals, and better able to administer home treatment (Ware, 1984). Further, educated women are more likely to engage in efforts to protect and manage resources (Norgaard \& York, 2005), which can improve maternal and neo-natal health by increasing access to clean water.

Lack of access to clean water and basic sanitation facilities also significantly impacts young girls attending school. This is in part because children suffering from diarrheal diseases miss school more frequently than children with access to clean water and basic sanitation. For girls, however, it is not just sickness that keeps them from attending school. Girls are disproportionately responsible for collecting water for the household, which tends to leave them with neither the time nor the energy for school (United Nations, 2010). Further, many girls in Sub-Saharan Africa also drop out of school because there are no separate latrines for girls and boys, which becomes particularly problematic when girls reach puberty (Buckingham-Hatfield, 2000). The resulting lack of education further marginalizes girls, reduces their chances of escaping poverty, and, ultimately, leads to a "vicious cycle," which reinforces other causes of maternal and neonatal mortality (Buchman, 1996). In short, educated girls that become mothers may experience lower rates of maternal and neo-natal mortality. However, to increase education in girls, access to clean water and basic sanitation at school must be provided. Therefore, if girls are provided with access to clean water and 
basic sanitation at school, their likelihood of attaining an education is drastically increased, which may result in them experiencing lower rates of maternal and neo-natal mortality in the future.

There are some directions for future research that follow from this study. First, we acknowledge that environmental factors affect women's (and early childhood) health; however, it may also be that water and sanitation have a unique and disproportionate impact on other aspects of a woman's life. For example, is the lack of access to an improved water source or sanitation facility more likely to adversely impact enrollment of girls in school at the primary and secondary levels than boys? Second, newly released data break down access to an improved water source and sanitation facility by rural and urban settings (World Health Organization \& United Nations Children's Fund, 2015). It is important to consider if the effects of these measures are more or less pronounced by geographical context to refine further our understanding of how water and sanitation affect health. Overall, it is imperative that researchers continue to study maternal and neo-natal mortality in Sub-Saharan Africa. Our study demonstrates that access to clean water and basic sanitation may help significantly reduce mortality rates, thus improving quality of life for countless women and children. Future research on maternal and neo-natal mortality in Sub-Saharan Africa should address how water and sanitation affects primary and secondary school enrollments for boys and girls, as well as the impact of rural verses urban settings on improved access to water and sanitation. Further research is necessary to understand how maternal and neo-natal mortality can be reduced in Sub-Saharan Africa.

\section{References}

Alvarez, J. L., Gil, R., \& Hernandez, V. (2009). Factors associated with maternal mortality in Sub-Saharan Africa: An ecological study. BMC Public Health, 9, 462-470.

Benova, L., Cumming, O., \& Campbell, O. M. R. (2014). Systematic review and meta-analysis: Association between water and sanitation environment and maternal mortality. Tropical Medicine and International Health, electronically published ahead of printing.

Blencowe, H., Cousens, S., Mullany, L. C., Lee, A. C., Kerber, K., Wall, S., Darmstadt, G. L., \& Lawn, J. E. (2011). Clean birth and postnatal care practices to reduce neonatal deaths from sepsis and tetanus: A systematic review and Delphi estimation of mortality effect. BMC Public Health, 11(Suppl 3): S11. 
Bradshaw, Y. W., \& Schafer, M. (2000). Urbanization and development: The emergence of international non-governmental organizations among declining states. Sociology Perspective, 43, 97-116.

Brady, D., Kaya, Y., \& Beckfield, J. (2007). Reassessing the effects of economic growth on well being in less developed countries, 1980-2003. Studies in Comparative International Development, 42, 1-35.

Bruor, D., \& Bream, K. (2004). An analysis of the determinants of maternal mortality in Sub-Saharan Africa. Journal of Women's Health, 13, 926-928.

Buchman, C. (1996). The debt crisis, structural adjustment, and women's education: Implications for status and development. International Journal of Comparative Sociology, 37, 5-30.

Buckingham-Hatfield, S. (2000). Gender and environment. London: Routledge.

Burroway, R. (2010). Schools Against AIDS: Secondary school enrollment and cross-national disparities in AIDS death rates. Social Problems, 57(3), 398-420.

Cairncross, S., Hunt, C., Boisson, S., Bostoen, C., Curtis, V., Fung, I. C., \& Schmidt W. P. (2010). Water, sanitation and hygiene for the prevention of diarrhoea. International journal of Epidemiology, 39(1), 193-205.

Cheng, J. J., Schuster-Wallace, C. J., Watt, S., Newbold, B. K., \& Mente, A. (2012). An ecological quantification of the relationships between water, sanitation and infant, child, and maternal mortality. Environmental Health, $11(1), 1-8$.

Chowdhury, Q. H., Islam, R., \& Hossain, K. (2010). Socio-economic determinants of neonatal, post neonatal, infant and child mortality. International Journal of Sociology and Anthropology 2(6), 118-25.

Cottingham, J., \& Royston, E. (1991). Obstetric fistula: A review of available information. Geneva: World Health Organization.

Dankelman, I., \& Davidson, J. (1988). Women and environment in the third world: Alliance for the future. London: Earthscan Publications Limited.

Dietz, T., York, R., \& Rosa, E. (2009). Environmentally efficient well-being: Rethinking sustainability as the relationship between human well-being and environmental impacts. Human Ecology Review, 16, 114-123.

Elo, I. T. (2009). Social class differentials in health and mortality: Patterns and explanations in comparative perspective. Annual Review of Sociology, 35, 553-72. 
Filmer, D., \& Pritchett, L. (1999). The impact of public spending on health: Does money matter? Social Science Medicine, 49, 1309-1323.

Frey, S. R., \& Field, C. (2000). The determinants of infant mortality in the less developed countries: A cross-national test of five theories. Social Indicators Research, 52(3), 215-234.

Freedom House. (2005). Freedom in the world: 2005. New York: Freedom House.

Gupta, G. R. (2004). Globalization, women and the HIV/AIDS epidemic. Peace Review 16(1), 79-83.

Halaby, C. N. (2004). Panel models in sociological research: Theory into practice. Annual Review of Sociology, 30, 507-544.

Handa, S., Koch, S., \& Ng, S. W. (2010). Child mortality in Eastern and Southern Africa. Population Review 49(1).

Howard, G., \& Bartram, J. (2003). Domestic water quantity, service level and health. Geneva: World Health Organization.

Hsiao, C. (2003). Analysis of panel data. New York: Cambridge University Press.

Jamieson, D., Theiler, R., \& Rasmussen, S. (2006). Emerging Infections and Pregnancy. Emerging Infectious Diseases, 12(11), 1638-43.

Jorgenson, A. K. (2014). Economic development and the carbon intensity of human well-being. Nature Climate Change, 127, 561-575.

Jorgenson, A. K., Dick, C., \& Mahutga, M. C. (2007). Foreign investment dependence and the environment: An eco-structural approach. Social Problems 54, 371-394.

London, B., \& Ross, R. J. S. (1995). The political sociology of foreign direct investment: Global capitalism and capital mobility, 1965-1980. International Journal of Comparative Sociology, 36, 198-219.

Malhotra, A., Warner, A., McGonagle, A., \& Lee-Rife, S. (2011). Solutions to end child marriage. Washington, DC: International Center for Research on Women.

Mamaye (2014). Facts and figures on the link between water, sanitation and hygiene (WASH) and maternal and newborn health $(\mathrm{MNH})$. London: Evidence for Action.

Mazur, A., \& Rosa, E. (1974). Energy and life-style: Massive energy consumption may not be necessary to maintain current living standards in America. Science, 186, 607-610. 
Moon, B., \& Dixon, W. (1985). Politics, state, and basic human needs: A crossnational study. American Journal of Political Science, 29, 6661-6694.

Norgaard, K., \& York, R. (2005). Gender equality and state environmentalism. Gender and Society, 19, 506-522.

Pandolfelli, L., Shandra, J. M., \& Tyagi, J. (2014). The International Monetary Fund, structural adjustment, and maternal mortality: A cross-national analysis of maternal mortality in Sub-Saharan Africa. Sociological Quarterly, 55, 119-142.

Peet, R. (2003). Unholy Trinity: The IMF, WB and WTO. London: Zed Books.

Prüss, A., Kay, D., Fewtrell, L., \& Bartram, J. (2002). Estimating the burden of disease from water, sanitation, and hygiene at a global level. Environmental health perspectives $110(5), 537-42$.

Rice, J. (2008). Material consumption and social well-being within the periphery of the world economy: An ecological analysis of maternal mortality. Social Science Research, 37, 1292-1309.

Rich, B. A. (1994). Mortgaging the earth: The World Bank, environmental impoverishment, and the crisis of development. Boston: Beacon Press.

Save the Children (2014). Ending newborn deaths: Ensuring every baby survives. London: Save the Children.

Scanlan, S. J. (2010). Gender, development, and HIV/AIDS: Implications for child mortality in less industrialized countries. International Journal of Comparative Sociology, 51, 211-232.

Scanlan, S. J., Jenkins, C., \& Peterson, L. (2007). Military famine, human rights, and child hunger: A cross-national analysis. Journal of Conflict Resolution, 51, 823-847.

Shandra, C. L., Shandra, J. M., \& London, B. (2011). World Bank structural adjustment, water, and sanitation: A cross-national analysis of child mortality in Sub-Saharan Africa. Organization \& Environment, 24(2), 107-29.

Shandra, J. M. (2007). The world polity and deforestation: A cross-national analysis. International Journal of Comparative Sociology, 48, 5-28.

Shandra, J. M., Shandra C. L., \& London, B. (2008). Women, non-governmental organizations, and deforestation: A cross-national study. Population and Environment 30(1-2), 48-72. 
Shen, C., \& Williamson, J. B. (1999). Maternal mortality, women's status, and economic dependency in less developed countries: A cross-national analysis. Social Science and Medicine, 49, 197-214.

Shordt, K., Smet, E., \& Herschderfer, K. (2012). Getting it right: Improving maternal health through water, sanitation \& hygiene. Haarlem, The Netherlands: Simavi.

United Nations (2010). State of the world's children. Oxford: Oxford University Press.

Vahter, M. (2009). Effects of arsenic on maternal and fetal health. Annual Review of Nutrition, 29(1), 381-399.

Ware, H. (1984). Effects of maternal education, women's roles and child care on child mortality. In W. H. Mosely, \& L. C. Chen (Eds.), Child Survival: strategies for research (pp. 191-214). New York: The Population Council.

Wickrama, K. A. S., \& Mulford, C. L. (1996). Political democracy, economic development, dependency, and social well-being in developing countries. Sociology Quarterly, 37, 375-390.

World Bank. (2005). World Development Indicators, World Bank. Washington: Development Data Group.

World Bank (2015). Millennium Development Goals. Goal 5: Improve Maternal Health by 2015. Washington: World Bank Group.

World Health Organization (2015). Global Health Observatory (GHO) data, Maternal Mortality. Geneva: World Health Organization.

World Health Organization (2010). Trends in maternal mortality: 1990-2008. Geneva: World Health Organization.

World Health Organization \& United Nations Children's Fund Joint Monitoring Programme (JMP) for Water Supply and Sanitation. (2015). 2015 Data. Retrieved from www.wssinfo.org.

Yardley, S. (2010). Joining the dots: Why better water, sanitation and hygiene are necessary for progress on maternal, newborn and child health. Teddington: Tearfund. 
This text is taken from Human Ecology Review, Volume 22, Number 1, 2015, published 2015 by ANU Press, The Australian National University, Canberra, Australia. 